\title{
Productivity studies on diatom cultures
}

\author{
D. WERNER \\ Botanisches Institut der Universität Marburg; \\ Marburg/Labn, Germany (FRG)
}

KURZFASSUNG: Produktivitätsstudien an Diatomeenkulturen. Die Generationszeiten von drei marinen bzw. euryhalinen Diatomeenarten werden in Beziehung zur Größe der Zellen verglichen. Die erreichten Generationszeiten betragen für Cyclotella cryptica 5, für Thalassiosira fluviatilis 8 und für Coscinodiscus asteromphalus $24 \mathrm{Std}$. Zellen von Coscinodiscus asteromphalus mit 200, 140 und $100 \mu$ Valvendurchmesser weisen annähernd die gleiche Generationszeit von 24 Std auf. Aus Generationszeit, Proteingehalt und DNS-Gehalt wird für verschiedene Zellen ein Quotient errechnet. Bei einem Stamm von Cyclotella cryptica haben sich Silicoborate als ein neuer, spezifisch wirkender Wachstumsfaktor erwiesen. Thalassiosira fluviatilis benötigt einen weiteren noch unbekannten Wachstumsfaktor. Für Cyclotella cryptica werden die verschiedenen Kulturbedingungen zusammengestellt, unter denen eine maximale Speicherung von Proteinen, Kohlenhydraten und Lipiden erreicht wird.

\section{INTRODUCTION}

The productivity of marine phytoplankton is the basis for the life in the sea. This statement is a commonplace: but what is productivity?

The concept of the productivity of an organism is not easy to define. Due to considerable differences in morphology and physiology, we cannot directly compare the productivity of a unicellular organism with that of a very active, but not growing, nervous cell in a mammalian tissue. Any definition requires at least two restrictions. (1) We must consider the level at which productivity is assessed (subcellular, cellular, tissue, individual or supra individual). (2) We must consider the product that is produced at this level per unit time, for example in terms of energy, number of special enzyme molecules or sum of all cell components. The attempt to define productivity becomes still more complicated by the fact that, within very short periods of time the product influences its own rate of production. The concept of productivity is, in fact, an aspect of the extensive field of biological regulations.

\section{METHODS}

Details about the biochemical and cultural methods, have been presented by WERnER (1966) and details about the media used by WERnER (1969). M e di u m I, 
used for cultivating Thalassiosira flwviatilis is the same as that employed in case of Surirella striatula (Nährlösung C). M e di u m II for Thalassiosira fluviatilis contains: $20 \%$ of medium II for Cyclotella cryptica, $25 \%$ of medium D for Coscinodiscus asteromphalus and 55\% aqua bidestillata. Me di u m II I for Thalassiosira fluviatilis is identical with medium II for Cyclotella cryptica plus $3 \mathrm{ml} / 1$ Silicoborate solution No. 1 and the vitamins of medium C for Surirella striatula (except Vitamin $\mathrm{B}_{12}$ ).

\section{RESULTS AND DISCUSSION}

One of the simplest and most suitable objects for productivity studies is the entire cell of a unicellular organism. The doubling time (= generation time) under optimal physiological conditions can be easily measured. In species of marine and brackish-water diatoms, we can compare cells of the same type, but with very different cell sizes in relation to their doubling time. We have, mainly, cultures of: Cyclotella cryptica (7-13 $\mu$ valve diameter), Thalassiosira fuviatilis (14-24 $\mu$ valve diameter) and Coscinodiscus asteromphalus (60-220 $\mu$ valve diameter).

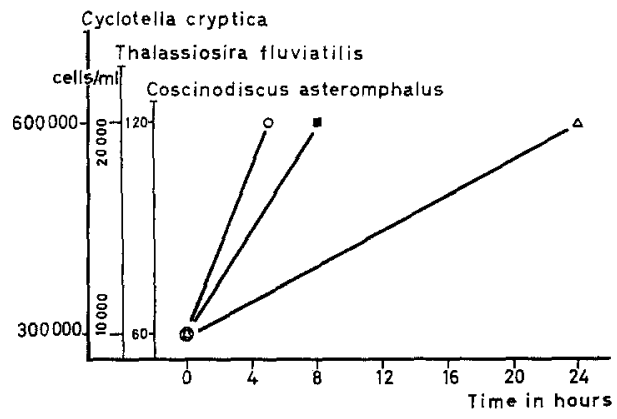

Fig. 1: Doubling times of Cyclotella cryptica (0), Thalassiosira fluviatilis (-) and Coscinodiscus asteromphalus $(\triangle)$

When we compare maximum population growth rates of these three species under optimal culture conditions, we find, as expected, that the doubling times are a function of the cell sizes of the diatom species studied (Fig. 1). A doubling time of $5 \mathrm{~h}$ for Cyclotella cryptica implies a reproductive factor of nearly 1,000 within $48 \mathrm{~h}$; therefore a doubling time of $8 \mathrm{~h}$ for Thalassiosira fluviatilis results in a factor of 64 and one cell division within $24 \mathrm{~h}$ for Coscinodiscus asteromphalus represents a reproduction of 4 within $48 \mathrm{~h}$. These values elucidate the importance of even little differences in doubling time upon the yield of batch cultures. Cyclotella cryptica reaches the same population growth rates as optimal growing cultures of Chlorella pyrenoidosa and Scenedesmus obliquus at identical temperatures (HoOgENHOUT \& AMESz 1965). Cyclotella cryptica tolerates high suspension densities. For instance, we can harvest from a 1401 culture vessel nearly $1 \mathrm{~kg}$ of diatoms within $48 \mathrm{~h}$. All literature data available on the shortest possible doubling times of diatoms (over a longer period of cultivation) lie between 5 and 24 h (LEWIN \& GurLLARD 1963). Using cells of Cos- 
cinodiscus asteromphalus at different stages of the meiotic life cycle (i. e. with different valve diameters) we looked for significant differences in the growth rates (Fig. 2). Cells with 200,140 and $100 \mu$ valve diameter, respectively, have nearly the same doubling times ( 1 cell division per day) during the logarithmic growth phase, although the

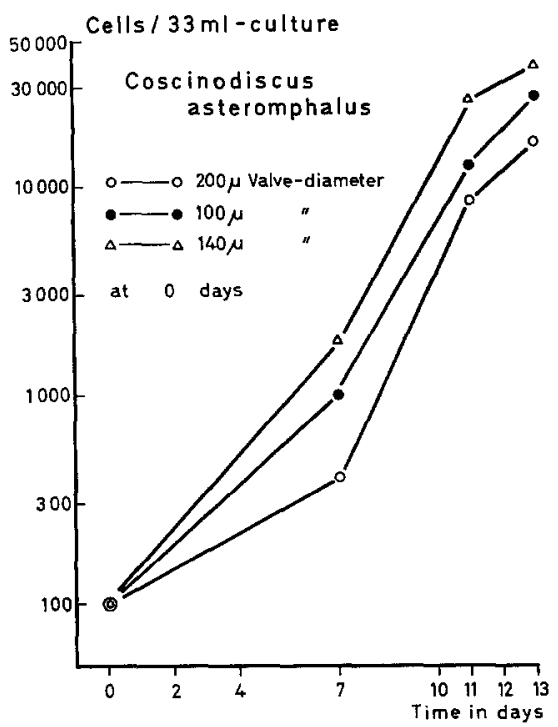

Fig. 2: Population growth of Coscinodiscus asteromphalus cells during different stages of the meiotic life cycle. $\left(25^{\circ} \mathrm{C} ; 14: 10\right.$ light-dark regime; $\left.1000 \mathrm{lux}\right)$

$140 \mu$ cells appear to grow a little faster. Since the length of the pervalvar axis does not change, the $200 \mu$ cells have approximately 4 times the volume of the $100 \mu$ cells. The production rates of protein in relation to the doubling time and the DNA content of the cells are given in Table 1.

Table 1

Doubling time, protein content and DNA content in diatoms

\begin{tabular}{|lcccc|}
\hline \multicolumn{1}{c}{$\begin{array}{c}\mathrm{A} \\
\text { Senecies }\end{array}$} & $\begin{array}{c}\mathrm{B} \\
\text { time } \\
(\mathrm{h})\end{array}$ & $\begin{array}{c}\text { Protein per } \\
\text { cell } \\
(\mu \mathrm{g})\end{array}$ & $\begin{array}{c}\mathrm{C} \\
\text { DNA per } \\
\text { cell } \\
(\mu \mathrm{g})\end{array}$ & $\mathrm{B}$ \\
\hline $\begin{array}{l}\text { Cyclotella } \\
\text { cryptica } \\
\begin{array}{l}\text { Coscinodiscus } \\
\text { asteromphalus } \\
(100 \mu)\end{array}\end{array}$ & 5 & $3.2 \times 10^{-5}$ & $1.5 \times 10^{-6}$ & 4.25 \\
$\begin{array}{l}\text { Coscinodiscus } \\
\text { asteromphalus } \\
(200 \mu)\end{array}$ & 24 & $5-6 \times 10^{-3}$ & $6-8 \times 10^{-5}$ & $3.1-3.5$ \\
\hline
\end{tabular}


A single cell of Cyclotella cryptica produces $3.2 \times 10^{-5} \mu \mathrm{g}$ protein within $5 \mathrm{~h}$ and a single cell of Coscinodiscus asteromphalus (100 $\mu$ valve diameter) $5.5 \times 10^{-3} \mu \mathrm{g}$. Calculated for $1 \mathrm{~h}$, the Coscinodiscus asteromphalus cell produces 40 times more protein than a Cyclotella cryptica cell. It is interesting, that the Coscinodiscus asteromphalus cell has a DNA content nearly 40 times as high as that of a Cyclotella cryptica cell (Table 1). If we divide the protein content by the DNA-content plus

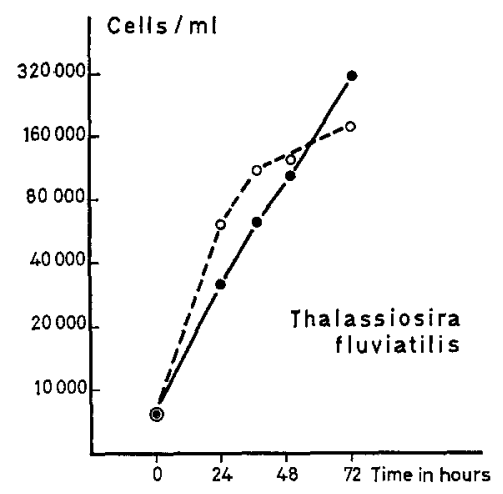

Fig. 3: Population growth of Thalassiosira fluviatilis $\left(27^{\circ} \mathrm{C} ; 6000\right.$ lux, continuous light). Culture in medium I ( 0 ) and in medium II (•)

the doubling time, we obtain almost similar values for these very different diatom species. If this is more than an accidental coincidence (and we will examine this possibility in some other well growing diatom species) it might be possible to calculate from the protein and DNA contents approximate values for the potential doubling times under optimum cultural conditions. It is still unknown whether the Coscinodiscus asteromphalus cells with 200 and with $100 \mu$ valve diameter (which have a different protein content) have the same, or a different, DNA content.

For all productivity studies an important prerequisite is well growing test organisms. Unfortunately, we are far from being able to cultivate all organisms in a synthetic medium under defined conditions. Apparently, we lack sufficient knowledge about the special physiology and biochemistry of our test organisms. In one clone of Cyclotella cryptica we have shown, for example, that a new growth factor, silicoborate (the first carbon free, physiologically required compound with 3 elements) is essential. Details about these compounds and experiments have been reported elsewhere (WERNER 1969).

I shall concentrate here on new experiments with Thalassiosira fuviatilis. We have cultivated this diatom in two different non-synthetic media, containing different concentrations of the same constituents. In one medium, the increase in cell number is faster within the first $24 \mathrm{~h}$ after inoculum and in the other, the cells grow to a higher density (Fig. 3). Since the media are somewhat different, this is not surprising. We incubated cells from these two cultures in parallel series in identical synthetic media and under exactly the same conditions of light and temperature. Over a range of more than 5 cell divisions the first group grew logarithmically and the second 
group revealed a significantly reduced growth rate within the first $24 \mathrm{~h}$, which later became even more reduced. The synthetic medium used in both cases, contains all common trace elements and vitamins and also, our new growth factor, silicoborate and it is the same medium we used for the culture of Cyclotella cryptica (Fig. 4).

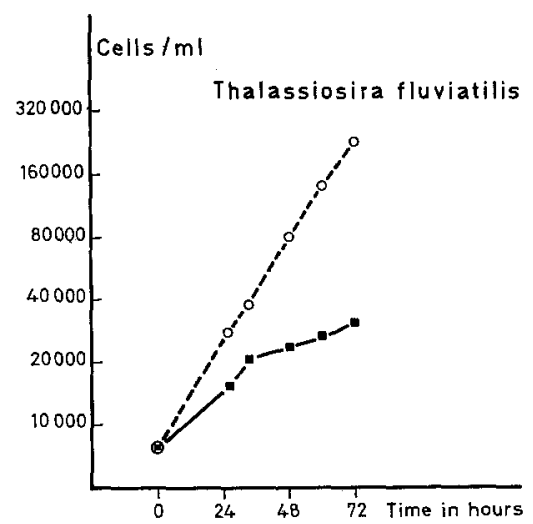

Fig. 4: Population growth of Thalissiosira fluviatilis $\left(27^{\circ} \mathrm{C} ; 6000\right.$ lux, continuous light). Culture in medium III, inoculum with cells from medium I $(0)$. Culture in medium III, inoculum with cells from medium II ( -$)$

The much better growing cells of Thalassiosira fluviatilis have, apparently, accumulated an unknown grow th factor which is responsible for the different growth rates. If this growth factor remains completely unsynthesized in the synthetic medium, it may be diluted 1:30 fold without losing its efficiency. We are still trying to identify this factor.

After considering productivity at the unicellular organism level, we shall now enquire into the synthesis of proteins, carbohydrates and lipids (sub-cellular level). The subject of these experiments was Cyclotella cryptica.

Table 2

Cyclotella cryptica. Contents of protein, carbohydrate and lipids as percentages of the ashfree "dry" weight $\left(27^{\circ} \mathrm{C} ; 10,000\right.$ lux $)$

\begin{tabular}{|lccc|}
\hline \multicolumn{1}{|c}{ Culture conditions } & $\begin{array}{c}\text { Protein } \\
(\% / 0)\end{array}$ & $\begin{array}{c}\text { Carbohydrate } \\
(\% / 0)\end{array}$ & $\begin{array}{c}\text { Lipids } \\
(\% / 0)\end{array}$ \\
\hline Continuous light & 40 & 40 & 16 \\
12 h darkness & 70 & 4 & 20 \\
N-deficiency for $24 \mathrm{~h}$ & 13 & 67 & 18 \\
N-deficiency for $11 \mathrm{~d}$ & 17 & 18 & 50 \\
Si (OH $)_{4}$-deficiency for $24 \mathrm{~h}$ & 31 & 19 & 38 \\
\hline
\end{tabular}

The maximum protein content of $70 \%$ is reached after a dark period of $12 \mathrm{~h}$, during this time the cells have metabolized the greater part of their carbohydrates to protein. The highest carbohydrate value is attained after incubation for almost 
$24 \mathrm{~h}$ in an $\mathrm{N}$-free medium. Initially, $\mathrm{N}$-deficiency causes no lipid accumulation in Cyclotella cryptica. Lipid storage occurs during a second phase over a period of many days. Quite another response was obtained under conditions of silicic acid deficiency, immediately, a storage of fat occurred. Table 2 indicates that it is possible, by employing different culture conditions, to obtain $50-70 \%$ for all 3 cell components analysed.

If we compare these values with the rates of productivity (i. e. fat production per $\mathrm{mg}$ protein per $\mathrm{h}$ ) interesting aspects emerge (Table 3 ).

Table 3

Cyclotella cryptica. Rates of lipid synthesis

\begin{tabular}{|cc|}
\hline Culture conditions & $\mu \mathrm{g}$ lipids/mg protein per $\mathrm{h}$ \\
\hline Normal medium & $60-70$ \\
N-deficiency & $14-16$ \\
$\mathrm{Si}(\mathrm{OH})_{4}$-deficiency & $130-140$ \\
\hline
\end{tabular}

In a complete medium, growing Cyclotella cryptica cells synthesize 60-70 $\mu \mathrm{g}$. Naturally, this is an average value over the whole mitotic life cycle. In spite of the high lipid accumulation, synthesis rates in $\mathrm{N}$-deficient cells amount to only $1 / 5$ of those of normal growing cells. This result implies that other syntheses are even more effectively inhibited than that of lipid production. In contrast, in $\mathrm{Si}(\mathrm{OH})_{4}$-deficient cells, a real enhancement of lipid synthesis occurs as compared to that of optimally growing cells. For nearly $6 \mathrm{~h}$, a production of $140 \mu \mathrm{g}$ lipids/per $\mathrm{mg}$ protein per $\mathrm{h}$ was obtained; this amounts to twice the value of well growing cells.

\section{SUMMARY}

1. Three different species of marine centric diatoms are used for physiological and biochemical studies: Cyclotella cryptica (7-13 $\mu$ valve diameter), Thalassiosira fluviatilis (14-24 $\mu$ valve diameter) and Coscinodiscus asteromphalus (60-220 $\mu$ valve diameter).

2. The shortest possible doubling time of these species under optimal cultivation conditions is: $5 \mathrm{~h}$ for Cyclotella cryptica $(300,000$ cells per $\mathrm{ml}) ; 8 \mathrm{~h}$ for Thalassiosira fluviatilis $(10,000$ cells per $\mathrm{ml}$ ); and $24 \mathrm{~h}$ for Coscinodiscus asteromphalus (50 cells per $\mathrm{ml})$.

3. In cultures of Coscinodiscus asteromphalus growth curves have been obtained for cells of different stages of the meiotic life cycle, i. e. with different valve diameters $(200 \mu, 140 \mu, 100 \mu)$. The species and the group specific differences are discussed with the object of illustrating the factors which produce the shortest possible life cycle.

4. Silicoborate (the first growth factor composed of 3 elements without carbon) is shown to be essential for the growth of a clone of Cyclotella cryptica in a highly purified medium. Another special growth factor is essential for optimal growth of Thalassiosira fuviatilis. 
5. The conditions for maximum storage of protein, lipid and carbohydrate in Cyclotella cryptica are compared with the conditions which allow maximum production of these components per unit time.

Acknoweledgements: I am grateful to Mrs. M. Penzel for very skillful technical assistance Some of these investigations have been supported by the Deutsche Forschungsgemeinschaft.

\section{LITERATURE CITED}

Hoogenhout, H., \& AmEsz, J., 1965. Growth rates of photosynthetic microorganisms in laboratory cultures. Arch. Mikrobiol. 50, 10-25.

Lewin, J. C., \& Guillard, R. R. L., 1963. Diatoms. Ann. Rev. Microbiol. 17, 373-414.

Werner, D., 1966. Die Kieselsäure im Stoffwechsel von Cyclotella cryptica Rermann, Lewin und GuILlard. Arch. Mikrobiol. 55, 278-308.

- 1969. Silicoborate als erste nicht C-haltige Wachstumsfaktoren. Arch. Mikrobiol. 65, 258-274.

Author's address: Dr. D. WERNER

Botanisches Institut der Universität

355 Marburg/Lahn

Pilgrimstein 4

Germany (FRG) 